\title{
Strategi mix-and-match vaksin COVID-19, seberapa efektifkah?
}

\author{
Rita Khairani \\ Departemen Ilmu Penyakit Dalam, Fakultas Kedokteran Universitas Trisakti, Indonesia \\ Email: rita.khairani@trisakti.ac.id
}

Dibandingkan dengan perkembangan vaksin COVID-19, kemunculan banyak varian baru menyebabkan peningkatan mortalitas dan morbiditas, distribusi vaksin secara global, ketersediaan suplai vaksin yang terbatas dan kejadian ikutan pasca imunisasi. Hal ini memunculkan kekhawatiran penurunan efektivitas vaksin yang telah ada. Setelah laporan kejadian tromboemboli akibat penggunaan ChAdOx1nCoV-19 dari AstraZeneca, beberapa negara Eropa mulai meneliti tentang penggunaan vaksin yang berbeda dengan dosis pertama atau yang disebut strategi mix-and-match atau vaksin heterolog. ${ }^{(1)}$ Vaksin heterolog melibatkan pemberian antigen penyakit yang sama atau serupa melalui dua tipe vaksin berbeda, dosis pertama untuk membentuk sistem imun dan dosis berikutnya dengan tipe berbeda untuk meningkatkan respon imun. ${ }^{(2)}$ Beberapa jenis vaksin yang banyak diteliti dalam konsep vaksin heterolog ini diantaranya kombinasi vaksin chimpanzee adenovirus-vectored vaccine (ChAdOx $1 \mathrm{nCoV-19)}$ atau AstraZeneca dengan vaksin mRNA-1273 atau vaksin Moderna, dan vaksin BNT162b2 atau vaksin Pfizer. ${ }^{(3,4)}$

Penggunaan vaksin heterolog telah dilakukan sebelumnya pada beberapa vaksin, seperti vaksin Ebola dan rotavirus, bahkan konsep vaksin heterolog vaksin rotavirus sudah dimulai sejak tahun 2006 di Amerika Serikat. (5) Terdapat dua macam vaksin rotavirus yaitu RotaTeq yang memerlukan tiga dosis dan Roratix yang memerlukan dua dosis pemberian. Kedua vaksin terbukti memiliki efikasi yang tinggi dan aman dalam penggunaannya, karena hanya sedikit sekali kasus intususepsi yang dilaporkan dibandingkan vaksin rotavirus sebelumnya, tetapi pada pelaksanaannya kadang sulit mendapatkan vaksin yang sejenis. ${ }^{(5)}$ Penelitian sebelumnya mengadakan uji acak terkontrol yang meneliti penggunaan vaksinasi rotavirus homolog dan heterolog. Penelitian tersebut menggunakan Roratix (RV1) dan RotaTeq (RV5) pada 1.393 bayi berusia 6-14 minggu. Sampel diacak menjadi 5 kelompok, 2 kelompok diberikan vaksin homolog dan sisanya diberikan vaksin heterolog, yaitu RV5-RV5-RV5, RV5-RV1-RV1, RV5-RV5-RV1, RV1-RV1, dan RV1-RV5-RV5. Jumlah sampel yang mengalami perubahan seropositif (Ig $\mathrm{A} \geq 20$ $\mathrm{U} / \mathrm{mL}$ ) pada pemberian dosis pertama kelompok heterolog berkisar $77-96 \%$ sampel dan tidak berbeda bermakna diantara kelompok lainnya. Sehingga disimpulkan pemberian vaksin heterolog aman dan menginduksi respons imun yang sama dibandingkan vaksin homolog. ${ }^{(5,6)}$

Penelitian penggunaan mix-and-match vaksin juga dilakukan pada vaksin Ebola. Mutua et al meneliti dewasa sehat yang dibagi menjadi 4 kelompok yang menerima vaksin Ebola heterolog. Kelompok pertama menerima vaksin Ad26.ZEBOV atau MVA-BN-Filo, diikuti vaksinasi kedua dengan vaksin berbeda selang 28 atau 56 hari dengan masing-masing memiliki kelompok plasebo. Tujuan utama penelitian yaitu menilai keamanan dan tolerabilitas vaksin heterolog. Hasil penelitian didapatkan, mayoritas efek samping yaitu sakit kepala dan nyeri lokal. Tidak ada perbedaan efek ikutan vaksin pada semua rejimen. Dua dosis vaksin heterolog yang menggunakan Ad26.ZEBOV dan MVA-BNFilo mempunyai imunogenik tinggi terhadap glikoprotein virus Ebola dan kadarnya bertahan setelah 360 hari pertama. ${ }^{(7)}$

Penggunaan mix-and-match vaksin COVID-19 telah dilakukan di India karena dengan populasi besar sulit untuk mendapatkan vaksin yang sama untuk dua kali pemberian. Pemberian vaksin kedua dengan tipe vaksin yang berbeda lebih baik daripada tidak memberikan booster sama sekali. ${ }^{(2)}$ Penelitian mix-and-match vaksin COVID-19 juga dilakukan di Spanyol yang 
melibatkan 663 subjek. ${ }^{(8)}$ Pertimbangan keamanan di beberapa negara Eropa merekomendasikan subjek yang telah menerima dosis pertama vaksin AstraZeneca mendapatkan vaksin yang berbeda untuk dosis yang kedua. Sebanyak 431 subjek yang telah mandapatkan vaksin AstraZeneca, setelah empat minggu mendapatkan vaksin Pfizer untuk dosis kedua dan sisa 232 subjek sebagai kontrol tidak mendapatkan booster. Hasil penelitian menunjukkan subjek yang menerima vaksin heterolog memiliki respon imun lebih kuat dan peningkatan antibodi lebih tinggi yang dapat mengenali dan menginaktivasi virus SARS-CoV-2 pada uji laboratorium. Sedangkan kelompok kontrol yang tidak mendapatkan booster tidak mengalami perubahan kadar antibodi. ${ }^{(8)}$

Penelitian Com-COV multisenter tersamar acak yang diadakan di Inggris membandingkan penggunaan vaksin homolog dan heterolog dari vaksin ChAdOx 1 nCoV-19 AstraZeneca dan vaksin BNT162b2 Pfizer-BioNTech. ${ }^{(3,9)}$ Sebanyak 830 subjek berusia minimal 50 tahun tanpa komorbid atau komorbid ringan dibagi menjadi empat kelompok. Mereka menerima ChAd/ChAd, ChAd/BNT, BNT/BNT atau BNT/ChAd dengan interval pemberian 28 dan 84 hari. Konsentrasi IgG anti-spike SARS-CoV-2 serum dan reaktogenisitas sistemik setelah 28 hari lebih tinggi pada kelompok vaksin heterolog dibandingkan vaksin homolog, serta imunogenisitas lebih tinggi pada kelompok ChAd/BNT dibandingkan dengan ChAd/ChAd. Tidak ada perbedaan bermakna efek samping yang ditimbulkan pada semua kelompok. Hasil penelitian dengan interval 84 hari masih berlangsung. ${ }^{(3,9,10)}$

Studi mix-and-match lainnya

menggunakan kombinasi vaksin ChAdOx $1 \mathrm{nCoV}$ 19 AstraZeneca dan booster menggunakan vaksin m-RNA (BNT162b2 Pfizer atau mRNA-1273 Moderna) dilakukan pada 216 subjek. Sebanyak 97 subjek kelompok ChAd/ BNT atau ChAd / mRNA1273, pada kelompok homolog dibagi 55 subjek kelompok ChAd/ChAd dn sisanya 64 subjek kelompok ChAd/mRNA1273. Konsentrasi IgG spike-spesific, antibodi neutralizing dan sel T CD4 spike-specific lebih tinggi bermakna pada kelompok heterolog dibandingkan kelompok ChAd ataupun mRNA. Kadar sel T CD8 juga terlihat lebih tinggi bermakna pada kelompok vaksin heterolog. Kesimpulan dalam penelitian tersebut menyatakan bahwa pemberian vaksin heterolog dapat menginduksi respons imunitas seluler dan humoral yang lebih kuat terhadap infeksi COVID-19 dengan profil reaktogenisitas yang dapat diterima. ${ }^{(11)}$

Gram et al melakukan penelitian mix-andmatch di Denmark melibatkan 144.360 subjek yang menggunakan ChAdOx1 pada dosis pertama dan 136.551 subjek diantaranya menggunakan vaksin m-RNA sebagai dosis kedua. Penelitian ini bertujuan untuk mengestimasi efektivitas vaksin (EV) bila menggunakan metode vaksin heterolog, menilai semua penyebab kematian karena COVID-19 dan mortalitas setelah mendapatkan vaksin. Hasil penelitian menunjukan EV vaksin heterolog adalah $88 \%$ (95\% confidence interval (CI): 83;92) yang dinilai pada 14 hari setelah dosis kedua. Hasil tersebut serupa dengan vaksin homolog m-RNA. Tidak ada subjek yang perlu dirawat dan mortalitas selama studi berlangsung, risiko. $^{(12)}$

Penelitian lain melibatkan 1200 subjek tengah dilakukan di Canada dengan membagi dua belas kelompok menggunakan vaksin homolog dan heterolog kombinasi ChAdOx1 AstraZeneca, mRNA-1273 Moderna atau BNT162b2 Pfizer dengan jarak pemberian 28 dan 112 hari. Studi ini meneliti respons imun, keamanan, kejadian ikutan pasca vaksinasi dan imunogenisitas pemberian dua tipe vaksin berbeda, dan interval terbaik antara dosis pertama dan kedua. ${ }^{(13)}$

World Health Organization (WHO) merekomendasikan penggunaan vaksin yang sama digunakan pada dosis pertama dan kedua. Jika produk vaksin COVID-19 yang berbeda tidak sengaja diberikan pada dosis kedua, maka tidak ada dosis tambahan. Saat ini pemberian vaksin heterolog hanya boleh diberikan jika manfaatnya lebih besar dari risikonya seperti dalam situasi pasokan vaksin yang terputus. ${ }^{(14)}$ Meskipun saat ini tidak ada data priming heterolog dengan produk vaksin lainnya, sejumlah besar studi klinis berbagai kombinasi vaksin dan jadwal saat ini sedang berlangsung. Strategic Advisory Group of Experts WHO akan meninjau data yang saat ini tersedia dan memperbarui rekomendasi yang sesuai. ${ }^{(14)}$

Situasi program vaksinasi COVID-19 di Indonesia, melalui data dari Kementerian Kesehatan Republik Indonesia per tanggal 26 
September 2021 menunjukkan $41.51 \%$ penduduk sasaran vaksinasi sudah mendapatkan vaksis dosis pertama sejak dilakukan program vaksinasi nasional pada Januari 2021. Saat ini terdapat 6 jenis vaksin COVID-19 yang digunakan di Indonesia, yaitu vaksin Coronavac, vaksin jadi buatan Sinovac asal Tiongkok, vaksin COVID-19, vaksin produksi Bio Farma dengan bahan baku dari Sinovac, vaksin AstraZeneca asal Inggris, vaksin Moderna dan Pfizer asal Amerika Serikat. ${ }^{(15,16)}$ Hingga saat ini, program vaksinasi di Indonesia masih menggunakan strategi vaksinasi homolog, kecuali pada tenaga kesehatan yang sudah menggunakan vaksin m-RNA sebagai booster dosis ketiga. Keberhasilan program vaksinasi di Indonesia dapat terhambat jika ketersediaan suplai vaksin homolog terganggu. Hal ini diakibatkan oleh keterbatasan fasilitas logistik dan distribusi vaksin sehingga pemberian dosis kedua tertunda atau terlambat dari jadwal yang telah ditentikan. Strategi mix-and-match vaksin COVID-19 dengan menggunakan vaksin heterolog dapat diterapkan untuk menangani permasalahan tersebut.

\section{REFERENSI}

1. Barros-Martins J, Hammerschmidt SI, Cossmann A, et al. Immune responses against SARS-CoV-2 variants after heterologous and homologous ChAdOx1 nCoV-19/BNT162b2 vaccination. Nat Med. 2021;27(9):1525-1529. doi: 10.1038/ s41591-021-01449-9.

2. Kunal S, Sakhtivel P, Gupta N, et al. Mix and match COVID-19 vaccines: potential benefit and perspective from India. Postgrad Med J Month 2021:0;1-3. doi:10.1136/ postgradmedj-2021-140648.

3. Shaw RH, Stuart A, Greenland $M$, et al. Heterologous prime-boost COVID-19 vaccination: initial reactogenicity data. Lancet. 2021;397(10289):2043-2046. doi: 10.1016/S01406736(21)01115-6.

4. Deming ME, Lyke KE. A 'mix and match' approach to SARS-CoV-2 vaccination. Nat Med. 2021;27(9):1510-1511. doi: 10.1038/s41591-02101463-x.

5. Libster R, McNeal M, Walter EB, et al. Safety and Immunogenicity of Sequential Rotavirus Vaccine Schedules. Pediatrics. 2016;137(2):e20152603. doi: $10.1542 /$ peds.2015-2603.

6. Byington CL, Maldonado Y. Rotavirus Vaccines-OK to Mix and Match. Pediatrics. 2016;137(2):e20153618. doi: 10.1542/peds.20153618.

7. Mutua G, Anzala O, Luhn K, et al. Safety and Immunogenicity of a 2-Dose Heterologous Vaccine Regimen With Ad26.ZEBOV and MVABN-Filo Ebola Vaccines: 12-Month Data From a Phase 1 Randomized Clinical Trial in Nairobi, Kenya. J Infect Dis. 2019;220(1):57-67. doi: 10.1093/infdis/jiz071.
8. Callaway E. Mix-and-match COVID vaccines trigger potent immune response. Nature. 2021;593(7860):491. doi: 10.1038/d41586-02101359-3.

9. Liu X, Shaw RH, Stuart ASV, et al. Safety and immunogenicity of heterologous versus homologous prime-boost schedules with an adenoviral vectored and mRNACOVID-19 vaccine (Com-COV): a single-blind, randomised, noninferiority trial. Lancet. 2021;398(10303):856869. doi: 10.1016/S0140-6736(21)01694-9.

10. Lin A, Liu J, Ma X, et al. Heterologous vaccination strategy for containing COVID-19 pandemic. medRxiv [Preprint]. [posted 2021 May 23]. doi: 10.1101/2021.05.17.21257134.

11. Schmidt T, Klemis V, Schub D, et al. Immunogenicity and reactogenicity of heterologous ChAdOx1 nCoV-19/mRNA vaccination. Nat Med. 2021;27(9):1530-1535. doi: 10.1038/s41591-02101464-w.

12. Gram MA, Nielsen J, Schelde AB, et al. Vaccine effectiveness when combining the ChAdOx1 vaccine as the first dose with an mRNA COVID-19 vaccine as the second dose. medRxiv [Preprint]. [posted 2021 Jul 28] doi: 10.1101/2021.07.26.21261130.

13. Canadian Immunization Research Network. Mix and Match of the Second COVID-19 Vaccine Dose for Safety and Immunogenicity (MOSAIC) [Internet]. Canadian Immunization Research Network; 2021 [updated 2021 Aug 25]. Available from: https:/clinicaltrials.gov/ct2/show/ NCT04894435.

14. World Health Organization. Interim statement on heterologous priming for COVID-19 vaccines [Internet]. World Health Organization; 2021 Aug 10. Available from: https:/www.who.int/ news/item/10-08-2021-interim-statement-onheterologous-priming-for-covid-19-vaccines.

15. Kementerian Kesehatan Republik Indonesia. Vaksinasi COVID-19 Nasional [Internet]. Jakarta: Kementerian Kesehatan Republik Indonesia; 2021 [cited 2021 Oct 26] . Available from: https:// vaksin.kemkes.go.id/\#/vaccines

16. Ophinni Y, Hasibuan AS, Widhani A, et al. COVID-19 Vaccines: Current Status and Implication for Use in Indonesia. Acta Med Indones. 2020;52(4):388-412. PMID: 33377885. 